\title{
Pengaruh Persepsi Siswa Setelah Mendapat Pembelajaran Menggunakan Model Course Review Horay Terhadap Hasil Belajar Siswa Kelas V Tema Lingkungan Sahabat Kita
}

\author{
Elsa Mega Putri ${ }^{1}$, Eka Sari Setianingsih ${ }^{2}$ \\ ${ }^{12}$ Program Studi Pendidikan Guru Sekolah Dasar, Fakultas IImu Pendidikan \\ Universitas PGRI Semarang \\ E-mail: elsamegaputri234@gmail.com
}

\begin{abstract}
Abstrak
Penelitian ini dilatar belakangi rendahnya hasil belajar siswa pada pembelajaran. Penelitian ini bertujuan untuk mengetahui pengaruh persepsi siswa setelah mendapat pembelajaran menggunakan model course review horay siswa kelas $V$ tema lingkungan sahabat kita. Jenis penelitian ini adalah penelitian eksperimen dengan menggunakan pendekatan kuantitatif dengan desain Pre Experimental Designs dengan bentuk One Group Pretest-Posttest Design. Populasi dalam penelitian adalah seluruh siswa kelas V SD N Karangtempel Semarang tahun pelajaran 2018/2019 yang terdiri dari 17 siswa. Hasil penelitian menunjukkan bahwa rata-rata hasil angket persepsi siswa menunjukkan sebesar $75.42 \%$ dan hasil belajar siswa berdasarkan uji-t diperoleh t_(hitung ) $>\mathrm{t}$ _(tabel ) yaitu sebesar $4.999>2.11$. Berdasarkan hasil analisis dapat disimpulkan bahwa ada pengaruh persepsi siswa setelah mendapatkan pembelajaran menggunakan model course review horay terhadap hasil belajar siswa kelas $\mathrm{V}$.
\end{abstract}

Kata Kunci: Persepsi, Model course review horay, Hasil Belajar

\begin{abstract}
This research is motivated by the low student learning outcomes in learning. This study aims to determine the effect of student perceptions after getting learning using the course review horay model of class $V$ students of our friends' environmental themes. This type of research is an experimental study using a quantitative approach with the design of Pre Experimental Designs in the form of One Group Pretest-Posttest Design. The population in the study were all fifth grade students of SD N Karangtempel Semarang in the academic year 2018/2019 which consisted of 17 students. The results of the study showed that the average results of the students' perception questionnaire showed $75.42 \%$ and student learning outcomes based on

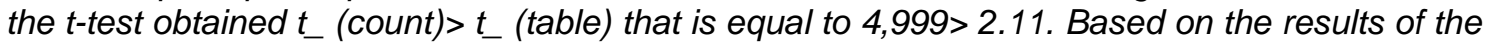
analysis it can be concluded that there is an influence of students' perceptions after getting learning using the horay course review model on the learning outcomes of fifth grade students.
\end{abstract}

Keywords: Perception, Model Course Review Horay, Learning Outcomes 


\section{Pendahuluan}

Pendidikan merupakan sarana untuk menghasilkan sumber daya manusia yang memiliki kemampuan dalam segala bidang khususnya bidang pengetahuan, keterampilan, sikap, serta mampu berpikir secara rasional. Keberhasilan suatu negara bisa dilihat dari sumber daya manusia yang terus meningkat. Peningkatan sumber daya manusia harus melalui pendidikan yang berkualitas bagi rakyatnya. Hal ini sesuai dengan Undang-Undang Republik Indonesia No. 20 Tahun 2003 pasal 3 tentang fungsi sistem pendidikan nasional yang menyatakan bahwa "Pendidikan nasional berfungsi mengembangkan kemampuan dan membentuk watak serta peradaban bangsa yang bermartabat dalam rangka mencerdaskan kehidupan bangsa, bertujuan untuk berkembangnya potensi peserta didik agar jadi manusia yang beriman dan bertakwa kepada Tuhan Yang Maha Esa, berakhlak mulia, sehat, berilmu, cakap, kreatif, mandiri, dan menjadi warga negara yang demokratis serta bertanggung jawab".

Proses belajar mengajar dapat dikatakan berhasil apabila seluruh siswa mampu memahami materi ajar dengan baik dan mendapatkan hasil belajar yang tinggi. Hasil belajar yang tinggi sangat diharapkan oleh siswa, guru maupun orang tua siswa. Akan tetapi, kenyataan yang berlangsung di lapangan saat ini hasil belajar siswa cenderung kurang memuaskan yaitu banyak siswa yang nilainya kurang dari Ketuntasan Kritreria Minimal (KKM). Dengan demikian, pada saat proses pembelajaran berlangsung guru kurang bisa mengkondisikan kelas serta guru hanya fokus pada buku yang diajarkan ke siswa dan siswa pun merasa bosan dengan pembelajaran yang hanya menggunakan metode ceramah saja, sehingga banyak siswa yang bersenda gurau sendiri di kelas.

Pembelajaran pada Tema 8 Lingkungan Sahabat Kita, Sub Tema 3 Usaha Pelestarian Lingkungan di SD hendaknya selalu disesuaikan dengan tingkat perkembangan siswa agar pembelajaran dalam tema tersebut menjadi menyenangkan dan bermakna bagi siswa. Pembelajaran dapat merangsang siswa untuk saling bekerjasama dan berpartisipasi aktif dalam pembelajaran, sehingga materi pelajaran yang disampaikan oleh guru dapat lebih jelas diterima dan dimengerti oleh siswa. Pola belajar yang menggunakan model Course Review Horay akan memberikan pengalaman belajar yang lebih bermakna dan lebih kuat melekat dalam ingatan atau pikiran siswa, sehingga hal tersebut akan berdampak pada pencapaian hasil belajar yang diperoleh oleh siswa. Demikian halnya yang terjadi di SD Negeri KarangTempel Semarang.

Selanjutnya, berdasarkan hasil observasi saya terhadap guru, siswa, dan proses pembelajaran di kelas, ditemukan beberapa permasalahan, yaitu sebagai berikut. 1. ketika mengajar guru hanya menuliskan beberapa materi ajar dipapan tulis, kemudian menjelaskan kembali materi ajar tersebut kepada siswa melalui ceramah, 2. guru belum menggunakan model-model pembelajaran yang inovatif, 3. guru belum menerapkan pendekatan scientific. Pola pembelajaran seperti di atas, jika diterapkan secara terus menerus akan mengakibatkan kegiatan pembelajaran tidak berjalan dengan efektif dan hasil belajar yang diperoleh oleh siswa cenderung rendah. Masalah rendahnya hasil belajar siswa perlu dicarikan solusi agar pembelajaran yang dilaksanakan dapat meningkatkan hasil belajar siswa. Di sekolah tersebut khususnya di kelas $\mathrm{V}$ guru kurang mampu mengkondisikan kelas serta kurang mampu dalam memberikan materi. Pada saat proses pembelajaran berlangsung guru hanya menggunakan Buku Paket Tematik sebagai media pembelajaran, dari pengamatan yang diperoleh siswa terlihat bosan, karena guru hanya fokus pada Buku Tematik saja, padahal materi akan mudah dipahami jika siswa belajar dengan menyenangkan. Dengan kurangnya guru menguasai materi yang diberikan kepada siswa maka pemahaman siswa mengenai materi yang diajarkan pun kurang.

Untuk meningkatkan pencapaian hasil belajar, maka diperlukan model pembelajaran yang tepat dalam proses pembelajaran. Berdasarkan hasil observasi saya didalam kelas, masalah rendahnya hasil belajar siswa perlu dicarikan solusi agar pembelajaran yang dilaksanakan dapat meningkatkan hasil belajar siswa. Untuk meningkatkan pencapaian hasil belajar, maka diperlukan model pembelajaran yang tepat dalam proses pembelajaran. Dalam pemilihan model pembelajaran yang nantinya akan membawa dampak positif bagi siswa. Dampak positif seorang siswa dapat diketahui salah satunya melalui persepsi dari diri siswa setalah mendapat pembelajaran menggunakan model tersebut. Slameto, (2010:102) mengatakan "persepsi adalah proses yang menyangkut masuknya pesan atau informasi ke dalam otak manusia". Indikator umum mengenai persepsi siswa dalam pembelajaran yaitu: Kecocokan Model Pembelajaran (Model pembelajaran yang digunakan oleh guru apakah menarik minat siswa sehingga siswa merasa tidak jenuh), Materi Pembelajaran (cara guru menyampaikan materi pembelajaran apakah mudah diterima atau justru membuat siswa 
merasa bingung), Media Pembelajaran (media harus sesuai dengan materi pembelajaran dan membuat siswa merasa tertarik dengan media tersebut), gaya mengajar (Gaya mengajar adalah suatu cara guru untuk mempermudah bagi siswa dalam rangka menerima materi berhasil atau tidaknya model pembelajaran yang diberikan oleh guru dapat diketahui. Dampak positif tersebut contohnya keaktifan siswa dalam pembelajaran yang nantinya akan berpengaruh pada pencapaian hasil belajar siswa. Salah satu model dan media pembelajaran yang memungkinkan setiap siswa berperan aktif dalam pembelajaran adalah model pembelajaran Course Review Horay.

Huda (2013: 229) Model pembelajaran kooperatif tipe Course Review Horay yaitu model pembelajaran yang dapat menciptakan suasana kelas menjadi lebih meriah dan mnyenengkan karena setiap kelompok yang dapat menjawab benar maka siswa tersebut diwajibkan berteriak "HOREY" atau yel-yel lainnya yang disukai. Metode ini berusaha menguji pemahaman siswa dalam menjawab soal, dimana jawaban soal tersebut dituliskan pada kartu atau kotak yang telah dilengkapi nomor.

Berdasarkan penelitian skripsi terdahulu terkait dengan model pembelajaran Course Review Horay seperti penelitian dari Asih Suryani (2016) mengenai pengaruh model Course Review Horay terhadap Pemahaman Matematis Dan Motivasi Belajar Matematika Siswa Sekolah Dasar Pada Materi Penjumlahan Dan Pengurangan Bilangan Bulat siswa kelas IV SDN Panyingkiran III menunjukkan penelitian berhasil sehingga dapat disimpulkan bahwa siswa lebih merasa senang dan lebih aktif ketika pembelajaran berlangsung karena pembelajaran lebih menarik dan mengandung unsur permainan sehingga siswa lebih mudah menerima materi.

Ada juga penelitian yang dilakukan oleh Nur Afidah tahun 2019 dengan judul Penerapan Model Pembelajaran Course Review Horay Berbantu Media Accordion Book Untuk Mengembangkan Nilai-Nilai Karakter Siswa menyimpulkan bahwa model course review horay berbantu media accordion book dapat membantu untuk mengembangkan nilai-nilai karakter siswa pada pembelajaran tematik. Hai ini dibuktikan dengan hasil uji t yang menunjukkan thitung $\geq$ ttabel yaitu $4.591 \geq 2.086$ maka Ho ditolak dan Ha diterima.

Berdasarkan uraian di atas, maka peneliti tertarik untuk mengadakan suatu penelitian di sekolah, adapun penelitian ini diberi judul "Pengaruh Persepsi Siswa Setelah Mendapat Pembelajaran Menggunakan Model Course Review Horay Terhadap Hasil Belajar Siswa Kelas V Tema Lingkungan Sahabat Kita".

Pengaruh dalam penelitian ini dimaksudkan, a) Untuk mengukur adanya hubungan antara persepsi siswa setelah pembelajaran model course review horay dengan hasil belajar, dan b) Untuk mengetahui adanya perbedaan hasil belajar siswa yang diperoleh dari persepsi siswa yang diperoleh dari persepsi siswa yang kurang baik.

Manfaat dari penelitian ini adalah untuk mengetahui hubungan antara persepsi siswa setelah mendapat pembelajaran model couse review horay dengan hasil belajar siswa kelas $\mathrm{V}$ tema VIII subtema 3 SDN KarangTempel Semarang.

\section{Metode}

Metode yang akan digunakan dalam penelitian ini adalah metode eksperimen. Dengan desain Penelitian menggunakan Pre Eksperimental Designs bentuk One-Group Pretest-Posttest Design. Pada desain ini terdapat pretest, sebelum diberi perlakuan. Dengan demikian hasil perlakuan dapat diketahui lebih akurat, karena dapat membandingkan dengan keadaan sebelum diberi perlakuan (Sugiyono,2015:74).

Populasi penelitian ini adalah seluruh siswa kelas V SD Negeri KarangTempel Semarang yang berjumlah 17 siswa. Sampel yang digunakan adalah seluruh siswa kelas V SD Negeri KarangTempel Semarang yang berjumlah 17 siswa.

Menurut Sugiyono (2015: 118) teknik sampling adalah teknik pengambilan sampel. Untuk menentukan sampel yang akan digunakan dalam penelitian, peneliti menggunakan teknik sampling jenuh, yaitu bahwa semua anggota populasi digunakan sebagai sampel karena jumlah populasi relatif kecil.

Teknik pengumpulan data yang digunakan pada penelitian ini yaitu Angket, dokumentasi, wawancara,observasi dan tes. Instrumen penelitian yang digunakan yaitu RPP, lembar observasi, dan soal tes. Instrumen soal tes sebelum digunakan diuji coba terlebih dahulu. Kemudian hasil uji coba diuji validitas, reliabilitas, taraf kesukaran,dan daya pembedaa untuk mengetahui kelayakan soal. Teknik analisis data yang digunakan pada penelitian ini yaitu 
uji normalitas awal, uji normalitas akhir, uji homogenitas awal, uji homogenitas akhir, uji korelasi dan regresi, uji ketuntasan belajar, dan uji banding (uji t) dua sampel.

\section{Hasil dan Pembahasan}

Penelitian ini merupakan penelitian eksperimen dengan member perlakuan. Penelitian ini menggunakan satu kelas yaitu kelas V.Desain yang digunakan dalam penelitian ini adalah PreEksperimental Design dengan menggunakan rancangan One-Group Pretest-Posttest Design. Berdasarkan design penelitian tersebut, pretest merupakan tes awal untuk mengetahui kemampuan awal peserta didik, dilaksanakan sebelum pembelajaran dan pemberian perlakuan. Setelah mengerjakan soal pretest kemudian peserta didik akan diberi perlakuan yaitu pembelajran menggunakan model course review horay.

Selanjutnya, pada akhir pembelajaran peserta didik akan diberikan soal posttest. Dengan pemberian pretest dan posttest akan diketahui apakah ada hubungan antara persepsi siswa setelah mendapat pembelajaran model couse review horay dengan hasil belajar siswa kelas V tema VIII subtema 3 SDN KarangTempel Semarang. Tipe soal yang digunakan pada pretest dan posttest sesuai dengan kisi-kisi soal yang telah dibuat. Soal pretest dan posttest masing-masing terdapat 25 butir soal pilihan ganda. Jika jawaban benar maka bernilai 1 , jika jawaban salah maka bernilai 0 .

Tabel 1. Rekpitulasi Nilai Pretest dan Posttest

\begin{tabular}{cccc}
\hline Jenis Tes & Nilai Tertinggi & Nilai Terendah & Rata-Rata \\
\hline Pretest & 88 & 24 & 57 \\
Posttest & 92 & 44 & 70 \\
\hline & & \multicolumn{2}{c}{ Sumber: Data Hasil Penelitian (2019) }
\end{tabular}

Berdasarkan Tabel diatas dapat dilihat bahwa selisih nilai pretest tertinggi dan terendah jelas berbeda. Pada pretest diperoleh nilai tertinggi yaitu 88, sedangkan nilai terendahnya 24 . Nilai rata rata kelas 57 dan hanya terdapat 5 peserta didik saja yang tuntas. Hal tersebut menunjukkan bahwa nilai pada pretest masih rendah dan belum mencapai Kriteria Ketuntasan Minimum (KKM) yaitu 65.

Seperti yang terlihat pada tabel, nilai posttest tertinggi yaitu mencapai 92 dan terendah 44 dengan nilai rata-rata 70 , dan hanya terdapat 5 orang peserta didik saja yang tidak mencapai Kriteria Ketuntasan Minimum (KKM). Hal tersebut menunjukkan bahwa terdapat peningkatan dari nilai pretest yang sebelum diberikan perlakuan dengan nilai posttest yang sudah diberikan perlakuan model course review horay. Kenaikan hasil belajar tema VIII sub tema III siswa tersebut ditandai dengan nilai rata-rata posttest lebih besar dari pretest yaitu $70>$ 57. Dari data pretest dan posttest tersebut dapat digambarkan dalam bentuk diagram sebagai berikut:

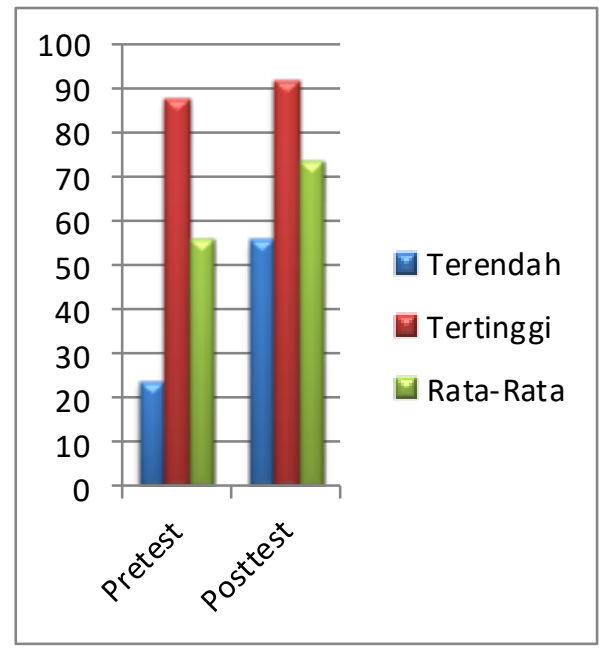

Gambar 1 Diagram Hasil Pretest dan Posttest 
Berdasarkan diagram di atas terlihat perbandingan antara nilai hasil ketuntasan siswa pada saat pretest sebesar $15 \%$ sedangkan hasil ketuntasan siswa pada posttest sebesar $85 \%$. Hal tersebut menunjukkan bahwa terdapat peningkatan sebesar $70 \%$ dari nilai pretest sebelum diberikan perlakuan dengan model course review horay.

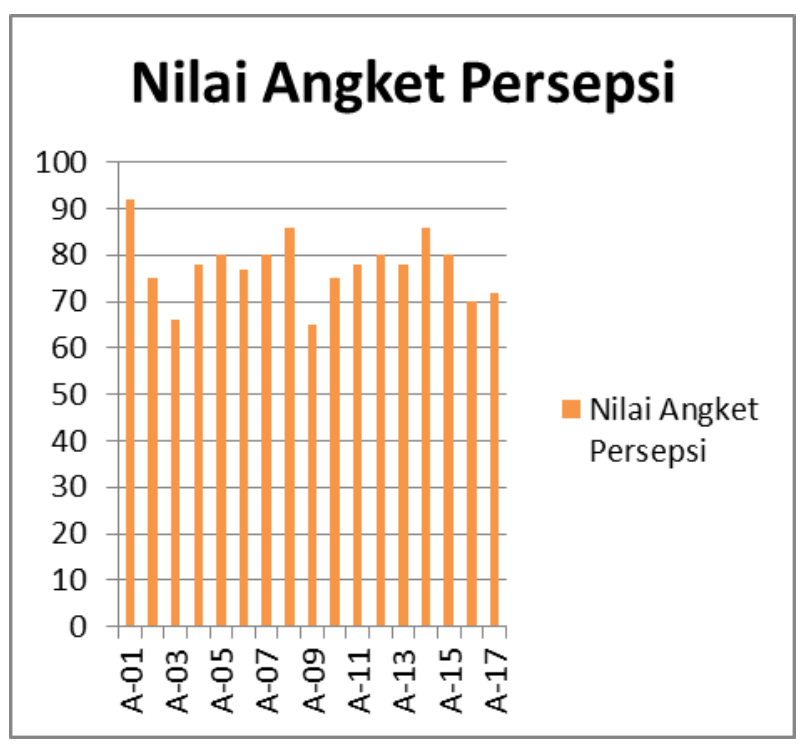

Gambar 2. Diagram Hasil Angket Seluruh Siswa

Dari Tabel 1 tersebut diperoleh KKM di sekolah 65. Data awal (pretest) sebelum diberi perlakuan nilai tertinggi 84 dan terendah 24 dari jumlah seluruh siswa 17 yang mencapai KKM hanya 5 siswa dan 12 siswanya lagi belum mencapai KKM. Kemudian diberi perlakuan (posttest) nilai tertinggi 92 dan terendah 44 dari 17 siswa ada 12 siswa yang sudah mencapai KKM sedangkan 5 siswa belum mencapai KKM ini dikarenakan siswanya yang kurang memperhatikan pada saat pembelajaran. Dan untuk nilai persepsi siswa didapatkan dari lembar angket yang diperoleh nilai tertinggi 92 dan terendah 62 .

Untuk menentukan pengaruh persepsi siswa setelah mendapat pembelajaran menggunakan model course review horay, diperlukan angket persepsi siswa untuk menilainya. Selain itu peneliti juga perlu melakukan pengmbilan data nilai pretest untuk dijadikan sebgai data awal. Data awal ini diambil sebelum peneliti memberikan perlakuan menggunakan model course review horay kepada siswa yang dijadikan kelas penelitian. Berdasarkan data awal (pretest) sebelum diberi perlakuan dan nilai akhir (posttest) hasil belajar siswa setelah diberikan perlakuan dengan menggunakan model course review horay dengan KKM yang ditentukan sebesar 65.

Untuk menguji kenormalan sampel yang digunakan dilakukan uji Liliefors. Uji normalitas awal dilakukan pada hasil pretest. Dengan $n=17$ dan taraf signifikan $5 \%$ diperoleh Lo $=0.115$ dan Ltabel $=0.206$. Jadi Lo < Ltabel maka Ho diterima artinya data siswa berasal dari populasi yang berdistribusi normal. Uji normalitas akhir dilakukan pada hasil posttest. Dengan $n=17$ dan taraf signifikan 5\% diperoleh $L o=0.167$ dan $L$ tabel $=0.206$. Jadi Lo $<$ Ltabel maka Ho diterima artinya data siswa berasal dari populasi yang berdistribusi normal.

Untuk menguji apakah kelompok tersebut homogen atau tidak maka dilakukan uji homogenitas. uji homogenitas awal dilakukan pada hasil pretest. Diperoleh $n=17$ dan taraf signifikan $5 \%$ dengan $\mathrm{dk}=5$ ternyata bahwa $\mathrm{F}$ hitung $<F$ tabel $1.82<5.99$. H0 diterima sehingga ketiga kelompok mempunyai varian yang sama (homogen). Uji homogenitas akhir dilakukan pada hasil posttest. Diperoleh $\mathrm{n}=17$ dan taraf signifikan $5 \%$ dengan $d b_{\text {pembilang }}=9$ dan $d b_{\text {penyebut }}=8$ di dapat $F_{\text {tabel }}=8.74$ ternyata bahwa $F_{\text {hitung }}<F_{\text {tabel }} 0.67<8.74$. $H_{0}$ diterima sehingga kedua kelompok mempunyai varians yang sama (homogen).

Untuk mengetahui korelasi antara persepsi siswa setelah mendapat pembelajaran menggunakan model course review horay terhadap hasil belajar siswa kelas $\mathrm{V}$ atau tidak maka digunakan uji korelasi. Dengan taraf signifikan $5 \%$ diperoleh Rhitung $=0.74455$ dan $\mathrm{R}$ tabel 0.482 maka Rhitung $>$ Rtabel $0.75>0.48$. Sehingga ada korelasi antara persepsi setelah 
mendapat pembelajaran menggunakan course review horay terhadap hasil belajar siswa kelas V.

Untuk menguji pengaruh persepsi siswa setelah mendapat pembelajaran menggunakan model course review horay terhadap hasil belajar siswa kelas $\mathrm{V}$ maka digunakan uji regresi.

Diperoleh:

1). Persamaan regresi linier sederhana

Perhitungan persamaan regresi linier sederhana antara persepsi siswa setelah mendapat pembelajaran menggunakan model course review horay terhadap hasil belajar siswa kelas $\mathrm{V}$ didapatkan hasil sebagai berikut:

$$
\begin{aligned}
& a=1.16476 \\
& b=0.90655 \\
& \text { Jadi persamaan } \\
& Y=a+b, Y=1.165+0.907 X
\end{aligned}
$$

\section{2). Uji Keberartian Regresi Linier Sederhana}

Perhitungan uji keberartian regresi linier sederhana digunakan untuk mengetahui linier antara model course review horay $(\mathrm{X})$ dengan hasil belajar siswa $(\mathrm{Y})$ apakah mempunyai keberartian atau tidak.

Berdasarkan data yang diperoleh bahwa $\alpha=0.05$ dan $\mathrm{dk}=8.7$ diperoleh $F_{\text {tabel }}=3.50$. Karena $F_{\text {hitung }}<F_{\text {tabel }}$ yaitu $1.503<3.50$ maka $H_{0}$ diterima. Jadi kesimpulannya ada korelasi antara persepsi siswa dengan hasil belajar yang linier.

\section{3). Uji Keberartian Koefisien Regresi Linier Sederhana}

Uji keberartian regresi linier ini digunaakan untuk mengetahui berarti atau tidak.

Diketahui $F_{\text {tabel }}=4.54$ sedangkan $F_{\text {hitung }}=5.30$ dengan taraf signifikan $\alpha=5 \%$ dengan $\mathrm{dk}=17$ sehingga diperoleh $F_{\text {hitung }}>F_{\text {tabel }}$ yaitu $5.30>4.54$. Dengan demikian $H_{0}$ ditolak.

d. Koefisien Determinasi

Koefisien determinasi ini digunakan untuk mengetahui seberapa besar pengaruh persepsi setelah mendapat pembelajaran menggunakan model course review horay terhadap hasil belajar siswa.

Diperoleh data bahwa $r_{2}=0.82124$ atau $82.2 \%$. Jadi pengaruh antara persepsi siswa pada model course review horay terhadap hasil belajar sebesar $82.2 \%$ dan dipengaruhi faktor lain yang tidak diteliti dalam penelitian ini.

Untuk membandingkan hasil belajar siswa yang persepsinya tinggi dengan siswa yang persepsinya rendah apakah ada perbedaan atau tidak maka digunakan uji t.

Dengan $\mathrm{n}=17$ dan taraf signifikan $5 \%$ maka diperoleh Thitung= 4.998774 dan Ttabel= 2.11 maka ada perbedaan hasil belajar antara siswa yang persepsi tinggi dengan siswa yang persepsinya rendah setelah mendapat pembelajaran menggunakan model Course Review Horay terhadap hasil belajar siswa kelas V SD N KarangTempel Tema Lingkungan Sahabat Kita.

Untuk menguji ketuntasan belajar maka digunakan uji ketuntasan belajar. Dengan siswa yang tuntas 12 anak dan siswa yang belum tuntas 5 anak, maka diperoleh ketuntasan belajar klasikal > ketuntasan belajar minimal, 71\% > 65\% maka pembelajaran dapat dikatakan berhasil.

Berdasarkan hasil perhitungan statistic yaitu uji normalitas awal,uji normalitas akhir, uji homogenitas awal, uji homogenitas akhir, uji korelasi dan regresi, uji $t$, dan uji ketuntasan belajar maka dapat disimpulkan bahwa ada pengaruh persepsi siswa setelah mendapat pembelajaran menggunakan model course review horay dengan hasil belajar siswa kelas $v$ tema lingkungan sahabat kita.

Model course review horay adalah salah satu bentuk model pembelajaran yang menciptakan suasana kelas menjadi menyenangkan sehingga siswa merasa tidak bosan dan menjadi lebih semangat. Sehingga siswa merasa tidak bosan dan menjadi lebih semangat dalam mengikuti pembelajaran dan setiap kelompok bertanggung jawab kepada kelompoknya untuk menjawab dan memahami pertanyaan yang diberikan oleh guru dengan benar sehingga nantinya memperoleh nilai atau poin tertinggi dan menjadi pemenang. Penelitian ini bertujuan untuk mengetahui pengaruh persepsi siswa setelah mendapat pembelajaran menggunakan model course review horay terhadap hasil belajar siswa kelas V SD N Karangtempel Semarang.

Berdasarkan paparan data yang diperoleh dari penelitian ini dapat disimpulkan bahwa model pembelajaran course review horay lebih baik dalam proses penelitian sehingga hasil belajar siswa SD N Karangtempel Semarang tema lingkungan sahabat kita menjadi meningkat. 
Pada penelitian ini disimpulkan bahwa ada pengaruh persepsi siswa setelah mendapat pembelajaran menggunakan model course review horay terhadap hasil belajar siswa kelas $\mathrm{V} D$ N Karangtempel Semarang.

\section{Simpulan dan Saran}

Berdasarkan rumusan masalah, pengajuan hipotesis, analisis data penelitian dan pembahasan,maka peneliti membuat kesimpulan bahwa ada pengaruh persepsi siswa setelah mendapat pembelajaran menggunakan model course review horay terhadap hasil belajar siswa kelas $\mathrm{V}$ tema lingkungan sahabat kita. Hal tersebut ditunjukkan dengan diperolehnya hasil pretest dengan rata-rata $57 \%$ mencapai ketuntasan $15 \%$ atau 5 siswa dan yang belum tentas $85 \%$ atau 12 siswa. Sedangkan diperoleh hasil posttest dengan rata-rata $70 \%$ mencapai ketuntasan $85 \%$ atau 12 siswa dan yang belum tuntas terdapat $15 \%$ atau 5 siswa. Sehingga hasil penelitian menunjukkan peningkatan rata-rata pretest dan posttest sebesar $70 \%$. Terbukti pada analisi tahap akhir melalui uji-t diperoleh hasil t_hitung>t_(tabel )yaitu $4.999>2.11$ maka H_O ditolak dan H_a diterima.

Berdasarkan kesimpulan diatas, maka saran yang diberikan dalam penelitian ini adalah sebagai berikut: 1) Pembelajaran dengan menggunakan model course review horay dapat menjadi alternative guru dalam melaksanakan proses pembelajaran untuk meningkatkan hasil belajar siswa khususnya dalam tema Lingkungan Sahabat Kita kelas V SD N Karangtempel, 2) Pembelajaran menggunakan model course review horay dapat digunakan sebagai inovasi baru dalam proses pembelajaran yang diharapkan guru, yaitu pembelajaran yang aktif,efektif, dan menyenangkan. Sehingga siswa dalam proses pembelajaran tidak bosan, 3) Dalam mengimplementasikan model course review horay dalam proses pembelajaran, harus dapat mengelola waktu dan mengkondisikan kelas dengan sebaik-baiknya agar dalam proses pembelajaran dapat berjalan dengan lancar, 4) Serta perlu adanya penelitian yang lebih lanjut untuk pengembangan dari penelitian ini..

\section{Daftar Pustaka}

Afidah, Nur, dkk. 2019. Penerapan Model Pembelajaran Course Reviiew Horay Berbantu Media Accordion Book Untuk mengembangkan Nilai-Nilai Karakter Siswa. Vol.24 No.1 2019.https://ejournal.undiksha.ac.id/index.php/MI/article/view/17407/10471

Arikunto, Suharsimi. 2015. Prosedur Penelitian Suatu Pendekatan Praktik. Jakarta: Rineka Cipta

Dimyati, dan Mudjiono. 2009. Belajar dan Pembelajaran. Jakarta: PT Rineka Cipta.

Huda, Miftahul. 2013. Model - Model Pengajaran dan Pembelajaran. Yogyakarta: Pustaka Pelajar

Kurniasih, Imas, dan Berlin Sani. 2015. Ragam Pengembangan Model Pembelajaran. Yogyakarta: Katapena

Latipah, Eka. 2017. Psikologi Dasar. Bandung: PT Remaja Rosdakarya

Robbins, P.Stephen dan Timothy A. Judge. 2012. Perilaku Organisasi. Jakarta: Salemba Empat

Slameto.2013. Belajar Dan Faktor-Faktor Yang Mempengaruhi. Jakarta: Rineka Cipta

Soegeng, A.Y. 2015.Dasar-dasar Penelitian. Semarang: IKIP PGRI Semarang Press

Sudjana. 2005. Metoda Statistika. Bandung: Tarsito

Sugiyono. 2016. Metode Penelitian Pendidikan. Bandung: Alfabeta

Suprijono, Agus. 2013. Cooperative Learning. Yogyakarta : Pustaka Belajar 
JP2, Vol 2 No 3, Tahun 2019

p-ISSN : 2614-3909 e-ISSN : 2614-3895

Suryani, Asih. 2016. Pengaruh Pendekatan Course Review Horay (Crh) Terhadap Pemahaman Matematis Dan Motivasi Belajar Matematika Siswa Sekolah Dasar Pada Materi Penjumlahan Dan Pengurangan Bilangan Bulat. Vol. 1, No. 1. Universitas Pendidikan Indonesia. Diakses pada tanggal 25 Oktober 2018.

Undang-undang Republik Indonesia No.20 Tahun 2003 tentang Sistem Pendidikan Nasional. Jakarta: Kemendiknas. 